\title{
Biosorption characteristic of Alcaligenes sp. BAPb.1 for removal of lead(II) from aqueous solution
}

\author{
Yu Jin ${ }^{1} \cdot$ Sumei $\mathrm{Yu}^{1} \cdot$ Chunying Teng ${ }^{1} \cdot$ Tao Song $^{1} \cdot$ Liying Dong $^{1} \cdot$ \\ Jinsong Liang ${ }^{1} \cdot$ Xin Bai $^{1} \cdot$ Xiuhong Xu ${ }^{1}$ Juanjuan $\mathbf{Q u}^{1}$
}

Received: 30 November 2016/Accepted: 6 April 2017/Published online: 31 May 2017

(c) Springer-Verlag Berlin Heidelberg 2017

\begin{abstract}
In this study, strain BAPb.1 was isolated from lead mining area and used as an adsorbent to remove lea$\mathrm{d}(\mathrm{II})$ ions from aqueous solution. The physicochemical characteristics, heavy metal resistance and antibiotic sensitivity of strain BAPb.1 were investigated. Biosorption capacity was evaluated by batch biosorption experiments, and isothermal characteristics were discussed. Atomic force microscopy (AFM), scanning electron microscopy (SEM), energy dispersive X-ray spectroscopy (EDX) and Fourier transform infrared spectrometry (FTIR) were conducted to explore the mechanism for lead(II) adsorption. Based on morphological and physiological characteristics as well as the phylogenetic analysis of $16 \mathrm{~S}$ rDNA sequences, strain BAPb. 1 was identified as a member of the genus Alcaligenes. It exhibited high resistances to multiple heavy metals such as lead(II), copper(II), zinc(II), nickel(II) and chromium(VI), and to antibiotics such as kanamycin, ampicillin, streptomycin, chloramphenicol, and tetracycline. The optimum conditions for maximum biosorption rate of $85.2 \%$ and maximum capacity of $56.8 \mathrm{mg} \mathrm{g}^{-1}$ were found at $\mathrm{pH}$ of 5 , adsorbent dosage of $1.5 \mathrm{~g} \mathrm{~L}^{-1}$ (dry weight), initial lead(II) concentration of $100 \mathrm{mg} \mathrm{L}^{-1}$, and contact time of $30 \mathrm{~min}$ at $30^{\circ} \mathrm{C}$. Biosorption isotherms were well fitted with Langmuir isotherm model. Mechanism analysis reveals that the lea$\mathrm{d}(\mathrm{II})$ ions may exchange with sodium and potassium ions, and the hydroxyl, carbonyl and phosphate groups on the cell surface can chelate the lead(II) ions, therefore, surface adsorption play significant role in the biosorption process.
\end{abstract}

Juanjuan Qu

juanjuan4050234@163.com

1 College of Resource and Environment, Northeast Agricultural University, Harbin 150030, China
Keywords Heavy metals · Biosorption · Lead(II) · Characteristics $\cdot$ Alcaligenes sp.

\section{Introduction}

The water discharged or leached from the mining areas is often polluted by heavy metals, which even at trace level is harmful to the health of human beings and eco-system (Gupta et al. 1998; Khani et al. 2010; He and Chen 2014; Latha et al. 2015). Lead ( $\mathrm{Pb})$ is a malleable and heavy posttransition metal generally applied in building construction, e-manufacturing, mining, lead-acid battery and so on (Gupta et al. 2011; Saleh et al. 2013). China is the main production and consumption country of $\mathrm{Pb}$ with annual output near to 135 million tons and consumption rate of 80 million tons. Moreover, backward technology, outdated equipment and unawareness of environment protection for Chinese enterprise aggravate the $\mathrm{Pb}$ contamination in ecological environment. $\mathrm{Pb}$ generally enters into human body through inhalation, ingestion, dermal contact, or transfer via the placenta. Acute and chronic exposure to $\mathrm{Pb}$ may cause anemia, liver and kidney disease, as well as central and peripheral nervous system damage (Özcan et al. 2009; Zhu et al. 2014). Young children are most vulnerable to $\mathrm{Pb}$ contamination, resulting in stunted growth and elevated blood $\mathrm{Pb}$ levels (BLLs) (Puyen et al. 2012).

In China, the threshold limit of $\mathrm{Pb}$-containing liquid from sewage and industrial effluents has been set to $1.0 \mathrm{mg} \mathrm{L}^{-1}$ (Environmental Quality Standard for Surface Water of China, GB8978-1996), but wastewater without efficient handling is hard to achieve the discharge standard. Many techniques such as ionic exchange, membrane separation and activated carbon adsorption are taken to 
remove lead ions from aqueous waste to ensure environmental safety, but these measures commonly require special equipment and rigorous experimental condition (Congeevaram et al. 2007). Biosorption process utilizes various natural materials possessing metal sequestering properties, which decrease the concentration of heavy metal ions in solution from ppm to ppb level. Furthermore, the biosorbents are readily available biomass from nature and have more distinct advantages, such as low cost and high adaptability to small-scale industries (Ucuna et al. 2009; Gupta and Nayak 2012). Three commercial biologicals including Chlorella vulgaris, Bacillus sp. and yeast have been exploited for heavy metal treatment by B.V.SORBEX Inc. Visa Tech Ltd. and US Bureau of Mines, respectively (Gabr et al. 2008). Currently more and more bacterial biomaterials have been applied in heavy metal removal (Huang et al. 2013). The functional groups (amino, hydroxyl, carboxyl and sulfate) of polysaccharides, proteins and lipids on their cell walls can act as binding sites to attract and combine metals ( $\mathrm{Ng}$ et al. 2009).

In the light of above facts, the present study aims to screen out a bacterial isolate from the lead mining area which can sustain high concentration of lead(II), and study its biosorption characteristics under various conditions, and reveal its possible mechanism by Atomic force microscopy (AFM), energy dispersive X-ray spectroscopy (EDX), Fourier transform infrared spectrometry (FTIR) techniques. These studies confirm the feasibility of the bacterium for the removal of toxic heavy metal lead(II) from wastewaters.

\section{Materials and methods}

\section{Isolation and identification of lead resistant bacterium}

To obtain the lead resistant bacterium, $100 \mathrm{~g}$ soil samples were collected from ten randomly selected sampling points (each point $10 \mathrm{~g}$ ) in a $\mathrm{Pb}$ mine ( $\mathrm{Pb}$ concentration was 2.0-3.5 $\mathrm{g} \mathrm{kg}^{-1}$ ) in Heilongjiang Province, China. One gram of soil was homogenized with $100 \mathrm{~mL}$ of sterile distilled water, and this soil suspension was serially diluted until a dilution of $10^{-5}$. Luria-Bertani (LB) agar medium contained serial concentrations (200-1000 mg L ${ }^{-1}$ ) of lead(II) [as $\mathrm{Pb}\left(\mathrm{NO}_{3}\right)_{2}$ ] were applied to select lead resistant bacterium. $0.2 \mathrm{~mL}$ of soil suspension $\left(10^{-5}\right)$ was plated on these LB agar plates using standard plate dilution method (Sheng et al. 2008). Agar plates were incubated at $30{ }^{\circ} \mathrm{C}$ for 3-4 days. Single colonies were picked and streaked onto a new LB agar plate for three times to obtain the pure isolates. The preliminary morphological, biochemical, and physiological characterizations of the pure isolates have been carried out according to the methods of Dong and Cai (2001), the 16S rDNA sequence analysis was referred to the method of Batta et al. (2013).

\section{Heavy metal resistance and antibiotic sensitivity}

The bacterial isolate was studied for its resistance to heavy metals and sensitivity to antibiotics. The exponential phase culture of bacterial isolate was inoculated aseptically on LB agar medium supplemented with heavy metals such as lead(II), copper(II), zinc(II), nickel(II), and chromium(VI). The metal salts used were $\mathrm{Pb}\left(\mathrm{NO}_{3}\right)_{2}, \mathrm{CuSO}_{4}, \mathrm{ZnCl}_{2}, \mathrm{NiCl}_{2}$, and $\mathrm{K}_{2} \mathrm{Cr}_{2} \mathrm{O}_{7}$ (Analytical reagent, Kermel, Tianjin, China) at concentrations ranging from 100 to $1200 \mathrm{mg} \mathrm{L}^{-1}$. The growth was observed after 24-h incubation up to $48 \mathrm{~h}$ at $30{ }^{\circ} \mathrm{C}$. Susceptibility to different antibiotics (kanamycin, ampicillin, streptomycin, chloramphenicol, and tetracycline) at a concentration ranging from 10 to $50 \mu \mathrm{g} \mathrm{mL}-1$ was determined by agar disk diffusion method. The bacterial isolate was classified as resistant or susceptible by examining the zone of inhibition on the lawn of bacterial culture after incubated for $24 \mathrm{~h}$ at $30{ }^{\circ} \mathrm{C}$ (Tripathi et al. 2011).

\section{Preparation of biosorbent and lead(II) solution}

The lead resistant strain was inoculated into sterile LB liquid medium and cultivated in a thermostatic shaker at $30{ }^{\circ} \mathrm{C}$. The live cells were harvested at late exponential phase by centrifugation at $8000 \mathrm{rpm}$ for $10 \mathrm{~min}$, then washed with phosphate buffered saline (PBS) and deionized water. The cells were frozen dried and ground into powder using mortar and pestle. This dead and powdered biomass was stored in a desiccator for the biosorption experiments.

The standard stock solution of lead(II) of $5 \mathrm{~g} \mathrm{~L}^{-1}$ was prepared by dissolving a certain amount of $\mathrm{Pb}\left(\mathrm{NO}_{3}\right)_{2}$ in deionized water. The stock solution was further diluted to the required concentrations before use.

\section{Batch biosorption experiments}

Batch biosorption experiments were carried out as functions of $\mathrm{pH}$, initial lead ion concentration, biosorbent dosage, and contact time in $250 \mathrm{~mL}$ Erlenmeyer flasks in a thermostatic shaker. The flasks were agitated with a rotational speed of $160 \mathrm{rpm}$ at $30{ }^{\circ} \mathrm{C}$, and the $\mathrm{pH}$ value was adjusted with $0.5 \mathrm{M} \mathrm{HCl}$ or $0.5 \mathrm{M} \mathrm{NaOH}$ solution. The influences of initial lead(II) concentration (10-150 $\left.\mathrm{mg} \mathrm{L}^{-1}\right), \quad \mathrm{pH} \quad$ (3-7), biosorbent dosage $\left(0.5-4.0 \mathrm{~g} \mathrm{~L}^{-1}\right)$, temperature $\left(22-40{ }^{\circ} \mathrm{C}\right)$ and contact time (5-50 $\mathrm{min})$ were evaluated. 
After the solution was centrifuged and filtered, lead(II) concentration of the supernatant was determined by atomic absorption spectrophotometer (AAS) (AA-6800, Shimadzu-GL, Japan). The experiments were conducted in triplicate and the mean values were calculated. Finally, the $Q$ (biosorption rate, \%) and the $q$ (adsorption capacity, $\mathrm{mg} \mathrm{g}^{-1}$ ) were calculated using Eqs. (1) and (2), respectively,

$Q=\frac{\left(C_{0}-C\right)}{C_{0}} \times 100 \%$

$q=\frac{C_{0}-C}{M} \times V$

where, $C_{0}$ and $C$ are the initial and final concentrations of lead(II) $\left(\mathrm{mg} \mathrm{L}^{-1}\right)$. The $V$ and $M$ are the volume of solution $(\mathrm{mL})$ and the weight of adsorbent $(\mathrm{g})$, respectively.

The Langmuir and Freundlich isotherm models were carried out by conducting biosorption experiments with different initial lead(II) concentrations (Freundlich 1906; Langmuir 1918). The experimental data conformed to the linear form of Langmuir and Freundlich model expressed as the following Eqs. (3) or (4), respectively,

$\frac{1}{q_{\mathrm{e}}}=\frac{1}{q_{\mathrm{m}}}+\frac{1}{K_{\mathrm{L}} \times q_{\mathrm{m}}} \times \frac{1}{C_{\mathrm{e}}}$

$L n q_{\mathrm{e}}=\ln K_{\mathrm{F}}+\frac{1}{n} \times \ln C_{\mathrm{e}}$

where, $q_{\mathrm{m}}$ and $K_{\mathrm{L}}$ are Langmuir constants related to biosorption capacity $\left(\mathrm{mg} \mathrm{g}^{-1}\right)$ and the energy of adsorption $\left(\mathrm{L} \mathrm{mg}{ }^{-1}\right) ; C_{\mathrm{e}}$ is equilibrium concentration of the metal (mg L ${ }^{-1}$ ) and $q_{\mathrm{e}}$ is the amount of the metals $(\mathrm{mg}$ ) adsorbed by BAPb. $1 ;(\mathrm{g}) K_{\mathrm{F}}$ and $1 / n$ are Freundlich constants which are related to the maximum adsorption capacity and adsorption intensity, respectively.

\section{Biosorption mechanism}

\section{AFM analysis}

To obtain complementary information, whole cells were examined by Nanoscope III $\alpha$ atomic force microscope (AFM) (Digital Instruments, Santa Barbara, CA, USA). Both Pb-loaded and $\mathrm{Pb}$-unloaded cells were collected by centrifugation, lightly rinsed in a sterile PBS solution and sterile deionized water, and then the specimens were transferred to glass slides and examined in air by AFM.

\section{SEM-EDX analysis}

The surface morphology of the strain BAPb. 1 before and after lead(II) biosorption was characterized using a scanning electron microscope (SEM) (QuANTA200 model,
FEI, USA). The elements were analyzed by an energy dispersive X-ray analysis system (EDX) (QuANTA200 model, FEI, USA). Prior to analysis, the samples were coated with a thin layer of gold under an argon atmosphere to improve electron conductivity and image quality.

\section{FTIR analysis}

Spectral analysis of the strain BAPb.1 (before and after biosorption) was done using an FTIR spectrometer (Alpha, Bruker, Germany) in the region of $4000-400 \mathrm{~cm}^{-1}$. The biosorbents were pressed into spectroscopic-quality $\mathrm{KBr}$ pellets with a sample/KBr ratio of $1 / 150$ and scanned for functional groups on cell surface.

\section{Results and discussion}

\section{Characteristics of the strain}

The culture grew well in $1000 \mathrm{mg} \mathrm{L}^{-1}$ lead(II) LB agar plate was isolated and designated as BAPb.1. The strain BAPb.1 is an aerobic, short rod shaped, flagella peritrichous (Fig. 1), and gram-negative bacteria. Colonies on LB solid plates were milky white to yellow in color, spherical, shiny, smooth, raised, and mucoid. The strain BAPb.1 grew evenly in LB liquid medium, forming biofilm on the top and sticky precipitate at the bottom. When grew on beef extract peptone agar medium and carbohydrates agar medium, most of the colonies appeared small irregular

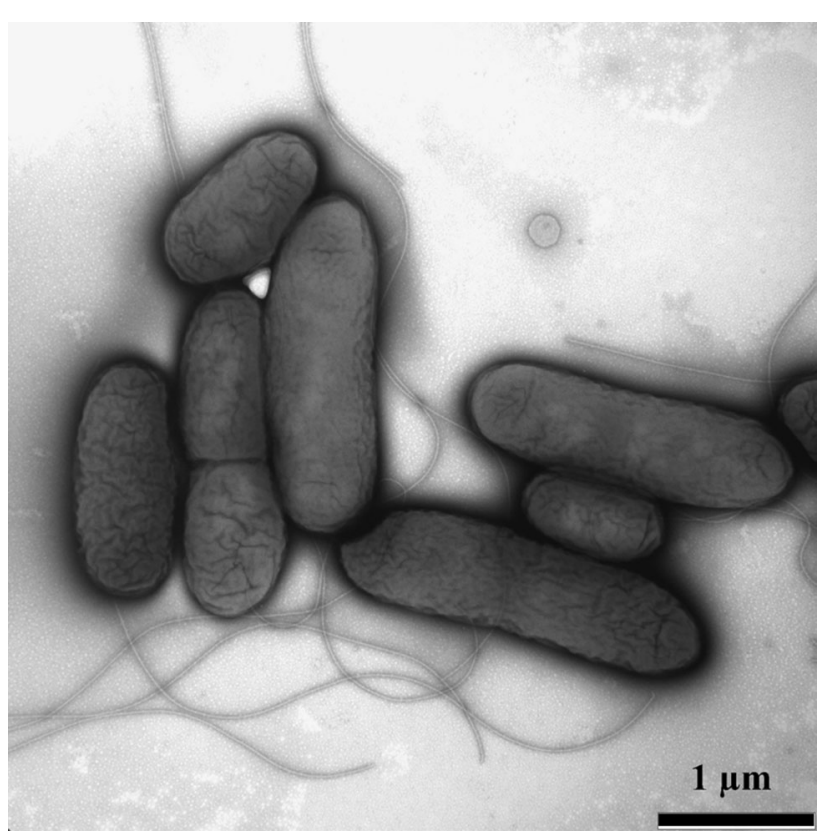

Fig. 1 The transmission electron microscope (TEM) graph of BAPb. 1 
margin, and produced ammonia, raising the $\mathrm{pH}$ value. Physicochemical characteristics of the strain were showed as follows: $(+)$ citrate, $(+)$ indole test, $(+)$ methyl red, $(+)$ gelatin liquefaction, $(+)$ Vopes-Prokauer $(\mathrm{V}-\mathrm{P})$, and $(-)$ D-mannose (Fig. 2).

The 16S rRNA gene of the strain BAPb.1 was cloned with the following PCR primer pairs: $16 \mathrm{~F} \quad\left(5^{\prime}\right.$ AGAGTTTGATCCTGGCTCAG- $\left.3^{\prime}\right)$ and 16R (5'GGTTACCTTGTTACGACTT- $3^{\prime}$ ). The reaction conditions were $94{ }^{\circ} \mathrm{C}$ for $5 \mathrm{~min}, 94{ }^{\circ} \mathrm{C}$ for $1 \mathrm{~min}, 58^{\circ} \mathrm{C}$ for $45 \mathrm{~s}, 72{ }^{\circ} \mathrm{C}$ for $1 \mathrm{~min}, 30$ cycles, and $72{ }^{\circ} \mathrm{C}$ for $10 \mathrm{~min}$. The PCR products were sequenced by the BGI Biotechnology Company (Beijing) and the obtained sequence was deposited in GenBank under accession number of KC337149. Based on multiple sequence alignment done by ClustalW and phylogenetic analysis by MEGA 5 (Fig. 3), strain BAPb.1 was found to have a close relationship with Alcaligenes sp. thus, it was identified as a species belonging to the genus Alcaligenes. Alcaligenes species were commonly found at polluted sites with chemical or metal resistance such as strain Achromobacter sp. AO22(EU696789)with a lead and copper tolerance (Ng et al. 2009) and BEN-4 (AY027504) with an arsenite-oxidizing capacity (Liu et al. 2012).

\section{Heavy metal resistance and antibiotic sensitivity}

Alcaligenes sp. BAPb.1 could grow on the plates containing $1000 \mathrm{mg} \mathrm{L}^{-1}$ lead(II), $600 \mathrm{mg} \mathrm{L}^{-1}$ copper(II), $600 \mathrm{mg} \mathrm{L}^{-1} \quad$ zinc(II), $400 \mathrm{mg} \mathrm{L}^{-1}$ nickel(II) and $400 \mathrm{mg} \mathrm{L}^{-1}$ chromium(VI), which suggested its broad resistance to heavy metals. On the other hand, the strain $\mathrm{BAPb} .1$ also could flourish on the plates containing $25 \mu \mathrm{g} \mathrm{mL}^{-1}$ kanamycin, $20 \mu \mathrm{g} \mathrm{mL}^{-1}$ ampicillin, $30 \mu \mathrm{g} \mathrm{mL}^{-1}$ streptomycin, $20 \mu \mathrm{g} \mathrm{mL}^{-1}$ chloramphenicol and $20 \mu \mathrm{g} \mathrm{mL}^{-1}$ tetracycline. It has been reported that heavy metal resistance is likely to link with antibiotic resistance (Ren et al. 2015). The results of resistant experiments indicate that Alcaligenes sp. BAPb. 1 is more adaptable to environmental contamination, and this characteristic has also been found in Enterobacter, Aeromonas, Moraxella, Pseudomonas, and Bacillus (Souza et al. 2006; Akinbowale et al. 2007).

\section{Batch biosorption experiments}

\section{Effect of initial lead(II) concentration}

Initial metal concentration can affect the adsorption efficiency greatly (Saleh et al. 2013). In this study, experiments were conducted firstly to investigate the effect of lead ion amount on biosorption. The initial lead(II) concentration was adjusted to the range of $10-150 \mathrm{mg} \mathrm{L}^{-1}$ under $\mathrm{pH} 5.5$, contact temperature of $30^{\circ} \mathrm{C}$, biosorbent dosage of $2 \mathrm{~g} \mathrm{~L}^{-1}$ and rotational speed of $160 \mathrm{rpm}$ for $30 \mathrm{~min}$. Figure 4a shows that the biosorption rate decreased from 97.8 to $65.8 \%$ with the initial lead(II) concentration increased from 10 to $150 \mathrm{mg} \mathrm{L}^{-1}$. On the other hand, the biosorption capacity rapidly increased from 4.9 to $44.1 \mathrm{mg} \mathrm{g}^{-1}$ with the initial lead(II) concentration increased from 10 to $100 \mathrm{mg} \mathrm{L}^{-1}$ and then kept stable when the initial lead(II) concentration was over $100 \mathrm{mg} \mathrm{L}^{-1}$. At lower concentrations, the ratio of the solute molecules to available surface sites was low, which resulted in higher biosorption rate and lower biosorption capacity. When the initial metal concentrations increased, the sites on biomass available for sorption became saturated gradually. It is necessary to identify the maximum saturation potential of a biosorbent, for which experiment should be conducted at the highest possible initial solute concentration (Vijayaraghavan and Yun 2008). As shown in Fig. 4a, higher biosorption occurred at lead(II) concentration of $125 \mathrm{mg} \mathrm{L}^{-1}$. To balance the biosorption capacity and the removal efficiency, the suitable initial lead(II) concentration was set as $100 \mathrm{mg} \mathrm{L}^{-1}$ under this condition, biosorption rate and biosorption capacity are $88.2 \%$ and $44.1 \mathrm{mg} \mathrm{g}^{-1}$, respectively.

\section{Effect of $p H$}

To test the effect of $\mathrm{pH}$ on biosorption by Alcaligenes sp. $\mathrm{BAPb} .1, \mathrm{pH}$ values were adjusted from 3 to 7 , the initial lead(II) concentration was revised to $100 \mathrm{mg} \mathrm{L}^{-1}$. It can be seen from Fig. 4b, the removal of lead(II) by BAPb.1 was strongly dependent on solution $\mathrm{pH}$. Both the biosorption rate and biosorption capacity increased with $\mathrm{pH}$ ascending from 3 to 5, the maximum biosorption rate of $88.4 \%$ and biosorption capacity of $44.2 \mathrm{mg} \mathrm{g}^{-1}$ were obtained at $\mathrm{pH}$
Fig. 2 The physiological and biochemical characteristics of BAPb.1 ( $C K$ means control group)

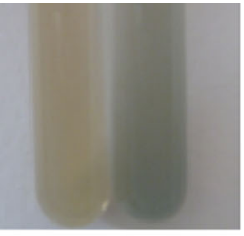

CK 1

citrate test

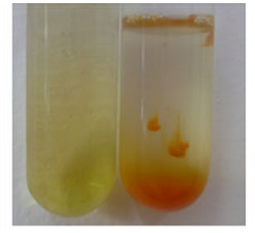

CK 2 indole test

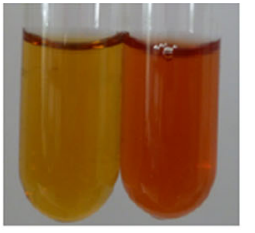

CK 3 methyl red

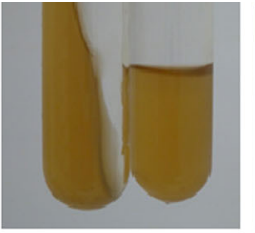

$4 \quad \mathrm{CK}$ gelatin liquefaction

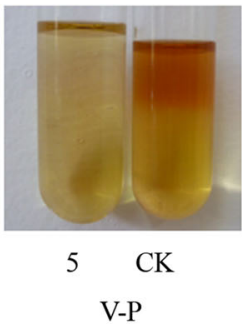


Fig. 3 Neighbor-joining tree showing the phylogenetic position of the isolate, Alcaligenes $\mathrm{BAPb} .1$, based on the 16S rRNA gene sequence. The numbers at the nodes indicate the level of bootstrap support based on the neighborjoining analysis of 100 replicates. Accession numbers are given in parenthesis

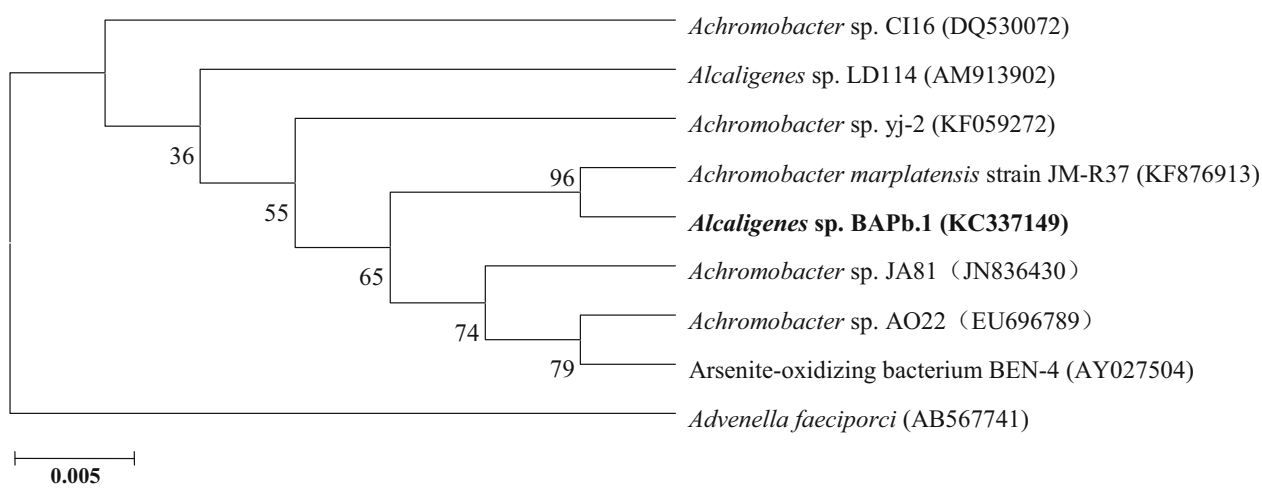

5. Then, both biosorption rate and biosorption capacity declined as the $\mathrm{pH}$ increased from 5 to 7 .

At low $\mathrm{pH}$ (3-4), functional anionic active sites might protonate at the biosorbent surface, bringing about a large number of cationic groups in solution, which could restrict the biosorption process for lead(II) (Rodriguez et al. 2006). More carboxyl groups might dissociate from the biomass surface when the $\mathrm{pH}$ increased from 4 to 5.5, which enhanced ion exchange capacity of the biosorbent and improved the combination of lead ions with the anionic ligands (Hubbe et al. 2011). When the $\mathrm{pH}$ was higher than 7 , the precipitation might occur, this process was related to insoluble metal hydroxide precipitation from the solution and should be avoided during sorption experiments to effectively distinguish between adsorption and precipitation (Onundi et al. 2010). Since the optimum pH of the biosorption process was about 5 , the $\mathrm{pH}$ value was revised to 5 in the following experiments.

\section{Effect of biosorbent dosage}

The effect of the biosorbent dosage was investigated by varying the biosorbent amounts from 0.5 to $4.0 \mathrm{~g} \mathrm{~L}^{-1}$. Figure $4 \mathrm{c}$ shows that the biosorption rate increased rapidly from 28 to $90 \%$ with the biosorbent dosage that increased from 0.5 to $2.0 \mathrm{~g} \mathrm{~L}^{-1}$ and then kept stable when the biosorbent dosage was over $2.5 \mathrm{~g} \mathrm{~L}^{-1}$. However, the biosorption capacity remained at about $58 \mathrm{mg} \mathrm{g}^{-1}$ when the biosorbent dosage was below $1.5 \mathrm{~g} \mathrm{~L}^{-1}$ and then sharply decreased with increasing biosorbent dosage. In the condition of high biosorbent dosages, the available solute was insufficient to completely cover the available exchangeable sites on the biosorbent, typically resulting in low biosorption capacity. In addition, the aggregation or overlapping of biosorbent surface area and competition for available sorption sites for metal ions adversely impacted the biosorption efficiency (EI-Sayed 2013). This result is in good agreement with those obtained in other studies (Masoudzadeh et al. 2011; Khadivinia et al. 2014). Based on the aforementioned result, the suitable biosorbent dosage was $1.5 \mathrm{~g} \mathrm{~L}^{-1}$.

\section{Effect of reaction temperature}

The experimental temperature ranging from 22 to $40{ }^{\circ} \mathrm{C}$ was set to examine its effect on biosorption. Figure $4 \mathrm{~d}$ illustrates that the biosorption rate and biosorption capacity increased from 65.6 to $86.3 \%$ and $43.7-57.5 \mathrm{mg} \mathrm{g}^{-1}$, respectively, with the temperature rising from 22 to $30{ }^{\circ} \mathrm{C}$. However, the results obtained in the present study showed no significant difference in biosorption rate or capacity between the lowest and highest temperatures. Energy-independent mechanisms suggest that adsorption efficiency can hardly be affected by temperature, since this biosorption is physicochemical (electrostatic forces) process in nature (Khadivinia et al. 2014). In our case, the biosorption is well performed at $30{ }^{\circ} \mathrm{C}$, which is taken as a cost-effective temperature for practice.

\section{Effect of contact time}

The effect of contact time (from 5 to $50 \mathrm{~min}$ ) on the removal of lead ions by BAPb.1 is shown in Fig. 4e. The process was very fast in the initial $20 \mathrm{~min}$, thereafter the process became slow and reached the equilibrium at $30 \mathrm{~min}$. The biosorption capacity and removal rate reached $59.2 \mathrm{mg} \mathrm{g}^{-1}$ and $88.8 \%$ in equilibrium period, and then the amount of biosorbed lead ions did not significantly change with time. Generally, the fast process initially involved physical biosorption or ion exchange with the biomass surface and the slow biosorption process at the later stage involved micro-precipitation or complexation, primarily in the microporous structure (Ding et al. 2014; Lan et al. 2014). In this case, the amount of lead ion biosorption did not exhibit time-dependent pattern after $30 \mathrm{~min}$. Therefore, the most suitable contact time was $30 \mathrm{~min}$.

\section{Biosorption isotherms}

Langmuir and Freundlich isotherm models have been widely used for modeling adsorption data. Langmuir isotherm represents chemisorption and assumes a monolayer 

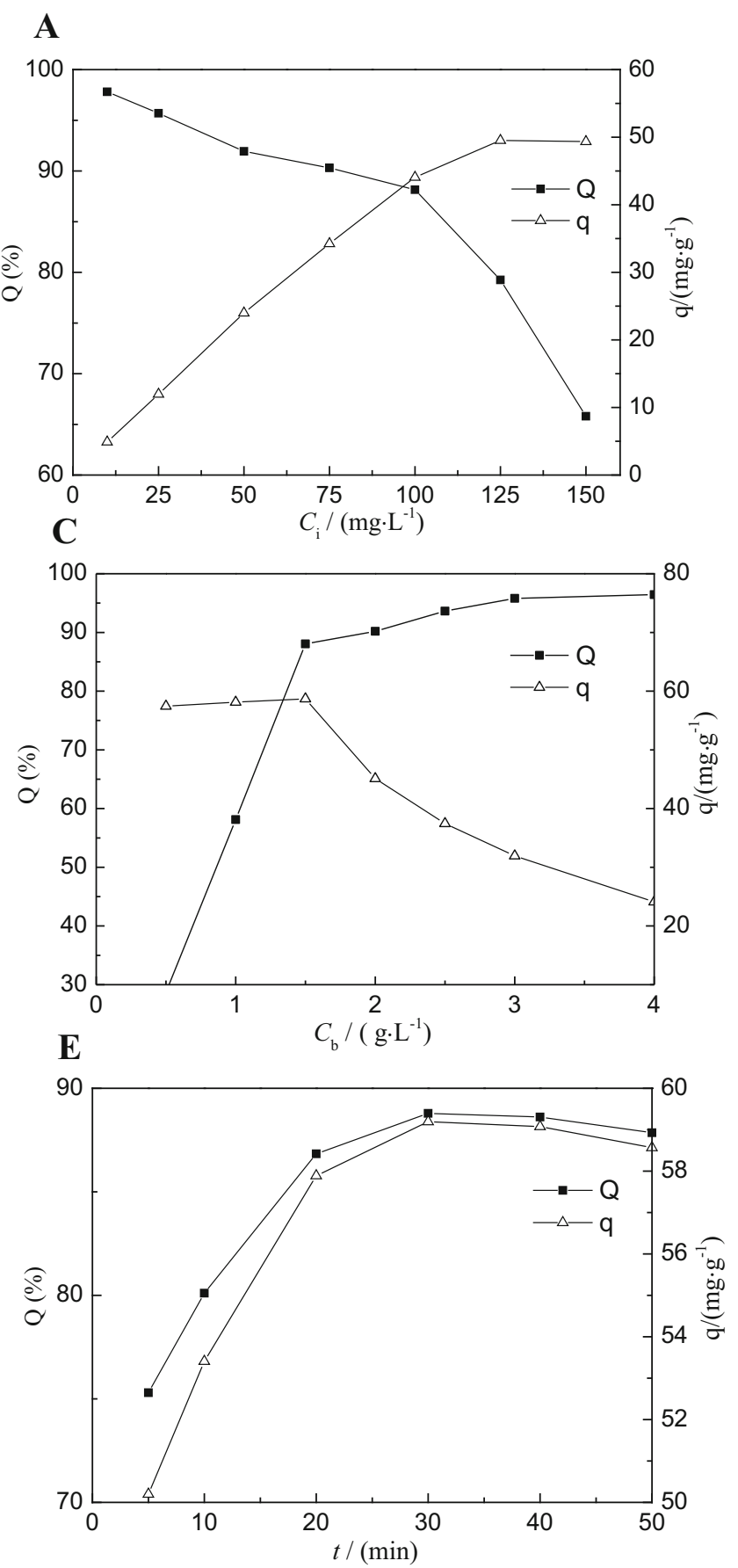
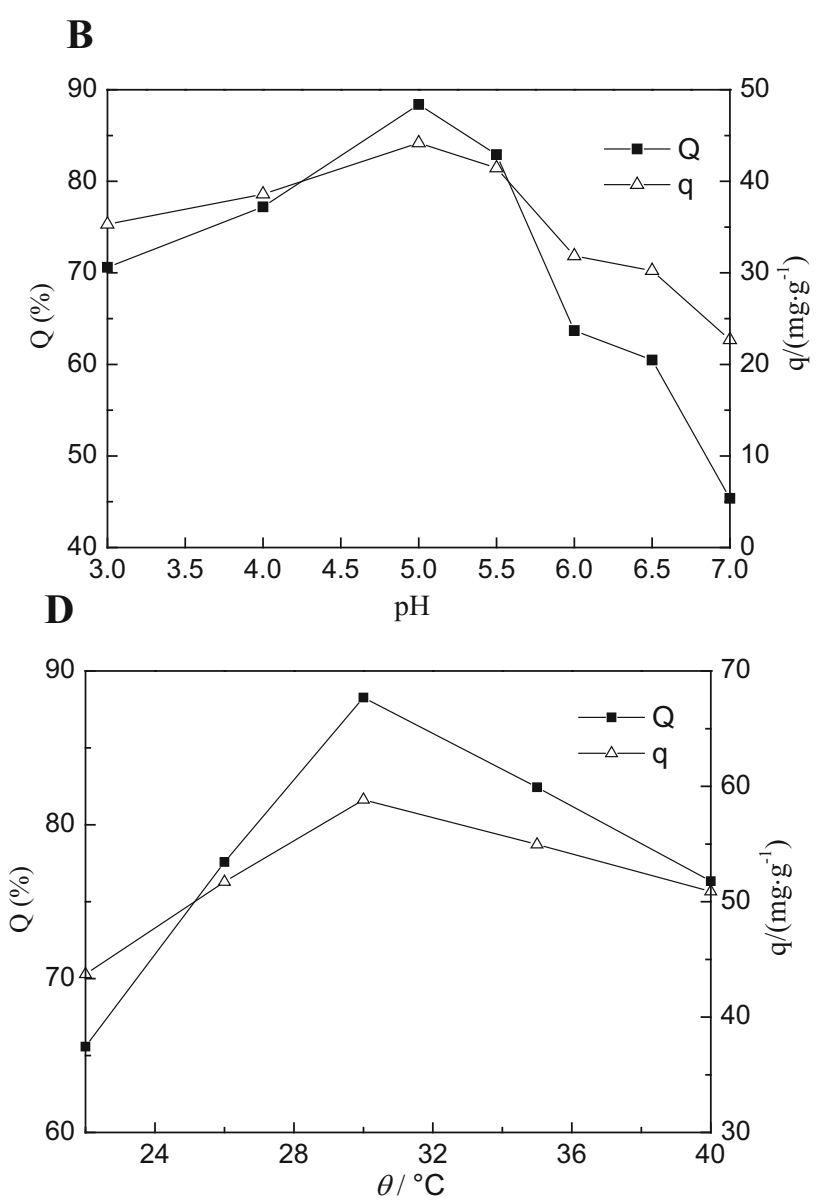

Fig. 4 Effect of physiochemical conditions on lead(II) biosorption. a lead(II) concentration, b pH, c biosorbent dosage, d temperature, e biosorption time

adsorption onto a surface containing a finite number of binding sites distributed homogeneously (Langmuir 1918). The Freundlich isotherm is used for modeling a heterogeneous surface of the adsorbent, indicating physisorption occurred on the adsorbent surface (Freundlich 1906). The adsorption pattern of lead(II) onto Alcaligenes sp. BAPb.1 was well fitted with the Langmuir and Freundlich models (Fig. 5; Table 1) whose $R^{2}$ values were 0.992 and 0.987 , respectively. Langmuir adsorption maximum, $q_{\max }$, was quite high with the value of $66.67 \mathrm{mg} \mathrm{g}^{-1}$. The Langmuir equilibrium coefficient, $K$, was $0.0446 \mathrm{~L} \mathrm{mg}^{-1}$. Freundlich adsorption capacity, the value of $k_{\mathrm{f}}$ was $3.1076 \mathrm{~L} \mathrm{~g}^{-1}$. Moreover, the Freundlich coefficient $(n)$ was 1.283 and $R^{2}$ was 0.987 . The $R^{2}$ and $q_{\max }$ values suggested that the Langmuir isotherm might be more suitable model for the data in this study because of the high coefficients of 

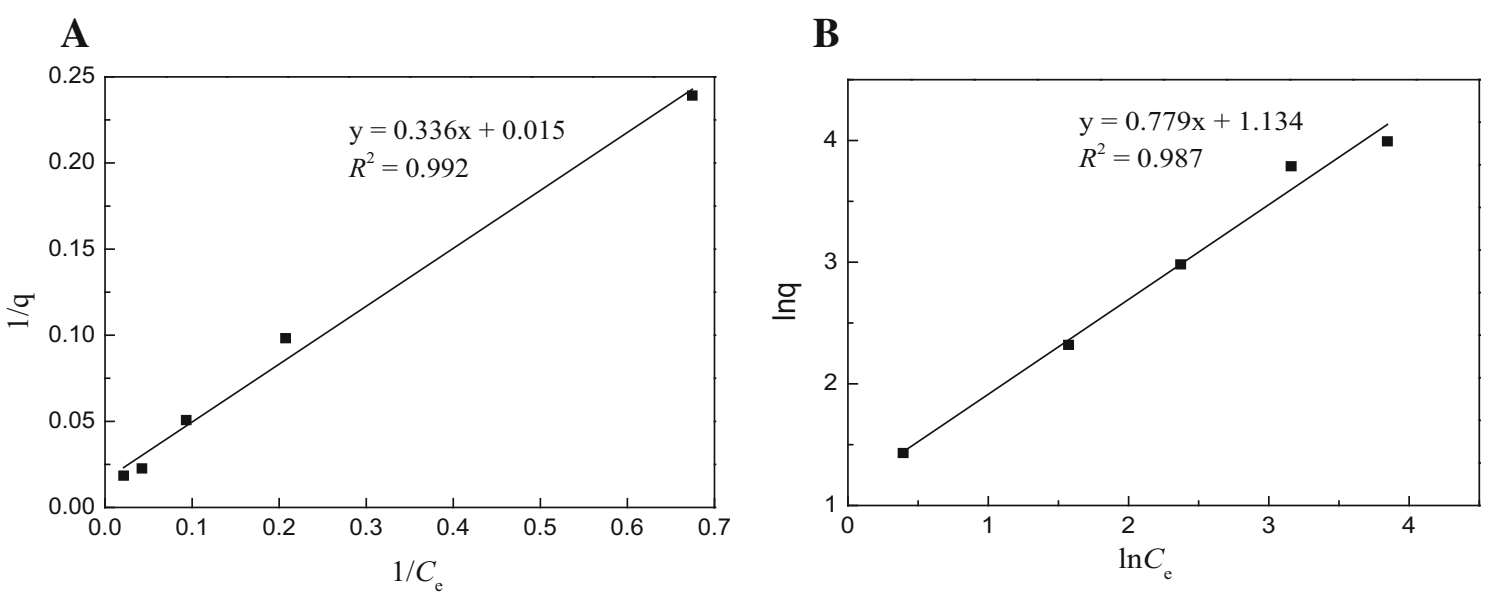

Fig. 5 Isotherms of lead(II) biosorption by BAPb.1. a Langmuir; b Freundlich

Table 1 Biosorption equilibrium constant obtained from Langmuir and Freundlich isotherms for biosorption of lead(II)

\begin{tabular}{|c|c|c|c|c|c|}
\hline \multicolumn{3}{|l|}{ Langmuir } & \multicolumn{3}{|c|}{ Freundlich } \\
\hline$Q_{\max } / \mathrm{mg} \mathrm{g}^{-1}$ & $K$ & $R^{2}$ & $K_{\mathrm{f}}$ & $N$ & $R^{2}$ \\
\hline 66.67 & 0.0446 & 0.992 & 3.1076 & 1.283 & 0.987 \\
\hline
\end{tabular}

Table 2 Uptake capacity of lead(II) by different biosorbents

\begin{tabular}{|c|c|c|}
\hline Biosorbent & $\begin{array}{l}Q_{\text {max }} / \\
\operatorname{mg~g}^{-1}\end{array}$ & References \\
\hline Geobacillus thermodenitrificans & 1.29 & $\begin{array}{l}\text { Chatterjee et al. } \\
\text { (2010) }\end{array}$ \\
\hline Staphylococcus saprophyticus & 100 & Ilhan et al. (2004) \\
\hline Pseudomonas aeruginosa PU21 & 110 & Sen et al. (2014) \\
\hline $\begin{array}{l}\text { Hot spring consortium of } \\
\text { microbes }\end{array}$ & 74.4 & Sen et al. (2014) \\
\hline Bacillus cereus & 36.7 & Pan et al. (2007) \\
\hline Alcaligenes sp. BAPb.1 & 66.7 & This study \\
\hline
\end{tabular}

determination, it was concluded that monolayer biosorption occurred at specifically homogeneous sites on the cell surface of Alcaligenes sp. BAPb.1 (Chergui et al. 2009).

The lead biosorption capacity of Alcaligenes sp. BAPb.1 and other bacteria reported was shown in Table 2, it suggested that the adsorption capacity $66.7 \mathrm{mg} \mathrm{g}^{-1}$ of $\mathrm{BAPb} .1$ is consistent with other bacteria; however, the different surface structure, functional groups and specific surface area of different strains result in the difference in adsorption capacity.

\section{Biosorption mechanism}

\section{AFM analysis}

Atomic force microscope has widely been used in microbiological studies to obtain topographical images of individual bacterial cell. To evaluate the changes of surface roughness, depth and width before and after lead(II) adsorption, the two-dimensional and its corresponding three-dimensional topographic AFM images of strain BAPb.1 cells were probed and showed together with the sectional analysis in Fig. 6.

The effect of lead ions on cell ultrastructure and surface morphology can be seen in Fig. 6. Before lead(II) adsorption, the cell surface was relatively intact, smooth, homogeneous, and the sectional depth of three random points was 76.6-77.3 nm (Fig. 6a), while after lead(II) adsorption, the cell had a different pattern, some obviously collapse atrophy occurred in some areas of the cell, which led to a high degree of heterogeneity, the sectional depth of three random points was 134.9-179.1 nm (Fig. 6b); the bonding of lead(II) with polysaccharide, protein and amide existed in exopolysaccharide (EPS) contributed to the increased thickness of the cell surface (Zhang et al. 2007). The results proved that lead(II) adsorption by strain BAPb.1 involved surface adsorption and micro-precipitation. The irregular shape and topography of cell was mainly caused by the interactions between lead(II) and surface of biosorbent. Moreover, the morphological changes after lead(II) adsorption were partly attributed to the different interaction forces between the cell and substrate surfaces (Chen et al. 2014).

\section{SEM-EDX analysis}

Scanning electron microscope was used to illustrate the surface morphology of BAPb.1 before and after lead(II) 

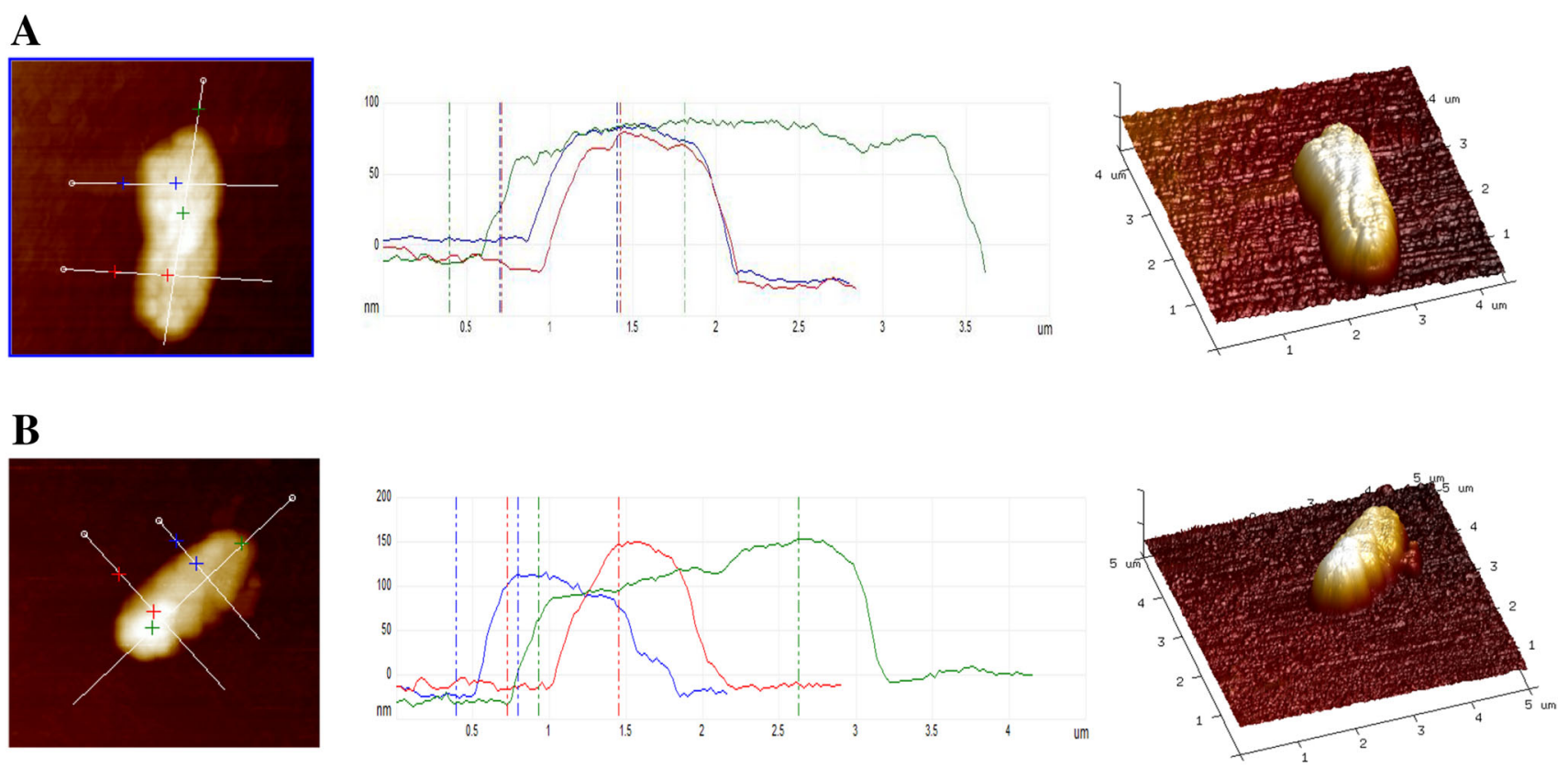

Fig. 6 AFM images of BAPb.1 before (a) and after (b) adsorbing lead(II)

Fig. 7 SEM images of BAPb.1 before (a) and after (b) adsorbing lead(II)
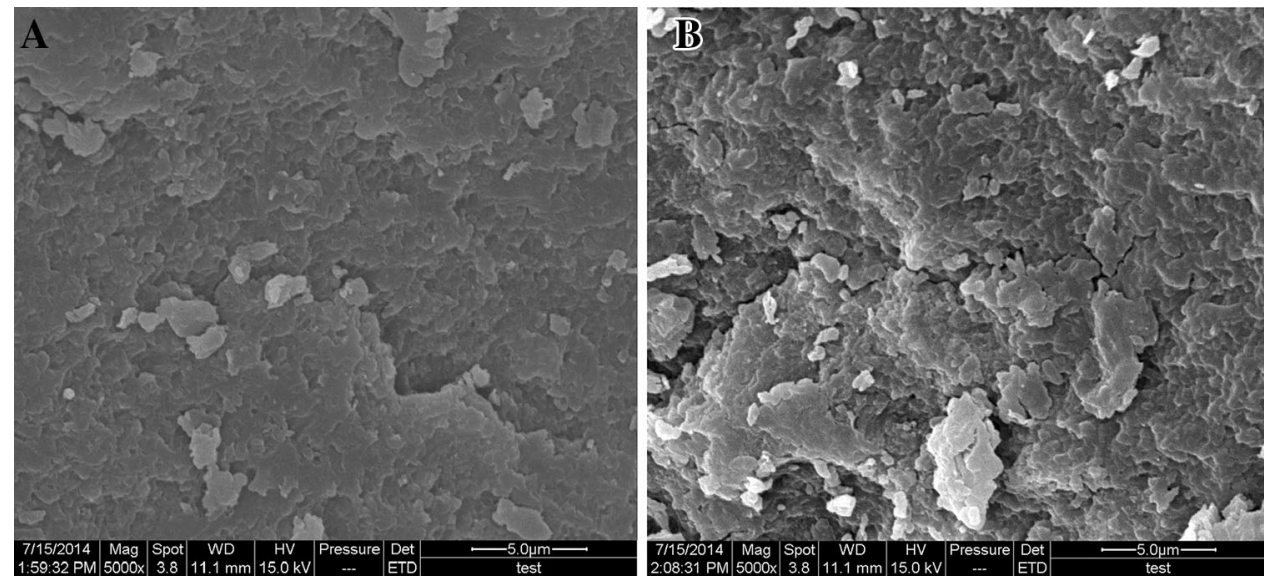

biosorption. Figure 7 a shows that the original cells remained intact, smooth, and closely connected with each other, providing a large surface area for biosorption. However, after contact with lead(II), the cells appeared to shrink and wrinkle, with the bright sections displayed due to the accumulation of lead (Fig. 7b). The EDX analysis showed that the elemental composition of strain BAPb.1 significantly changed after lead(II) adsorption (Fig. 8; Table 3). The atomic percentage of element $\mathrm{Pb}(\mathrm{at} \%)$ was 1.77 , that of $\mathrm{C}, \mathrm{N}$ and $\mathrm{O}$ (at\%) decreased, respectively, from 62.00 to $61.57,20.7$ to 19.13 and 14.19 to 13.17 , while that of P increased from 2.57 to 4.11 after lead(II) uptake. The results showed that lead(II) adsorption could covalently bond with $\mathrm{C}-, \mathrm{N}-, \mathrm{O}-$ and $\mathrm{P}$-containing functional groups. As previously reported, the functional groups (carboxylate, hydroxyl, amino and phosphate) on bacterial cell surface were responsible for lead(II) adsorption (Monteiro et al. 2011; Sedighi et al. 2012). Thus, it was rational to speculate that adsorption of lead(II) by strain BAPb.1 mostly occurred on the cell surface. Moreover, atomic percentage of $\mathrm{Na}$ and $\mathrm{K}$ decreased, respectively, from 0.25 to 0.13 and 0.30 to 0.12 after contact with $\mathrm{Pb}$, which revealed that $\mathrm{Pb}$ possibly exchanged with $\mathrm{Na}$ and $\mathrm{K}$ on the cell surface (Chojnacka et al. 2005; Kazy et al. 2006).

\section{FTIR analysis}

It is essential to identify the functional groups on the biomass involved in adsorbing process with FTIR, which is helpful to understand the surface-bonding mechanism. FTIR spectrum in and without the presence of lead(II) revealed significant differences in the absorption peaks of functional groups (Fig. 9a, b). FTIR spectrum revealed the peaks of hydroxyl 
Fig. 8 EDX spectrum of BAPb. 1 before (a) and after (b) adsorbing lead(II)
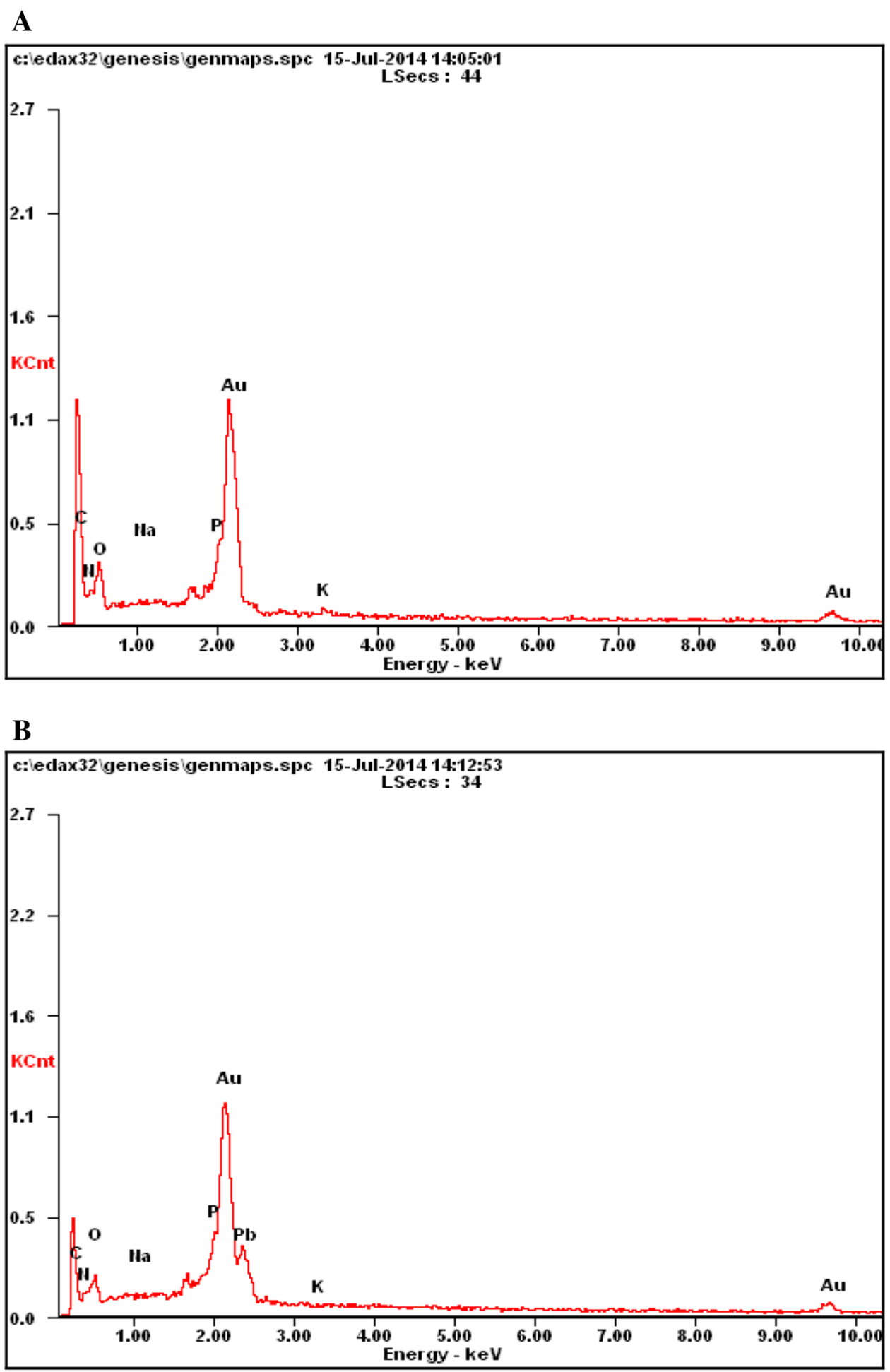

groups shifting from 3307.08 to $3305.09 \mathrm{~cm}^{-1}$, at the same time the peak intensity increased and the peak width sharpened, indicating the formation of more $-\mathrm{OH}$ complexation; anti-symmetric stretching peak of $-\mathrm{CH}_{2}$ shifted from 2926.06 to $2925.20 \mathrm{~cm}^{-1}$ by interaction with lead(II); symmetric stretching peak of $\mathrm{C}=\mathrm{O}$ migrated from 1653.56 to
$1653.85 \mathrm{~cm}^{-1}$ with the peak intensity decrease; amide $\mathrm{C}-\mathrm{N}$ peak shifted from 1238.54 to $1233.69 \mathrm{~cm}^{-1}$ and tended to be weakend; organic phosphate anti-symmetric stretching peak of $\mathrm{P}-\mathrm{O}-\mathrm{C}$ shifted from 1057.30 to $1054.22 \mathrm{~cm}^{-1}$; $\mathrm{C}-\mathrm{S}$ peak around $699 \mathrm{~cm}^{-1}$ now tended to be enhanced; $\mathrm{NH}-$ stretching around $1540 \mathrm{~cm}^{-1}$ was found to be responsible for lead(II) 
Table 3 Elemental content analysis of BAPb.1 before and after adsorbing lead(II)

\begin{tabular}{|c|c|c|c|c|c|}
\hline \multirow[t]{2}{*}{ Element } & \multicolumn{2}{|l|}{ Before } & \multirow[t]{2}{*}{ Element } & \multicolumn{2}{|l|}{ After } \\
\hline & $\mathrm{wt} \%$ & at $\%$ & & wt $\%$ & at $\%$ \\
\hline$C K$ & 54.81 & 62.00 & $C K$ & 42.99 & 61.57 \\
\hline$N K$ & 21.34 & 20.70 & $N K$ & 15.58 & 19.13 \\
\hline$O K$ & 16.71 & 14.19 & $O K$ & 12.25 & 13.17 \\
\hline $\mathrm{NaK}$ & 00.42 & 00.25 & $\mathrm{NaK}$ & 00.17 & 00.13 \\
\hline$P K$ & 05.85 & 02.57 & $P K$ & 07.40 & 04.11 \\
\hline$P b M$ & - & - & $P b M$ & 21.35 & 01.77 \\
\hline$K K$ & 00.86 & 00.30 & $K K$ & 00.27 & 00.12 \\
\hline Matrix & Correction & ZAF & Matrix & Correction & ZAF \\
\hline
\end{tabular}
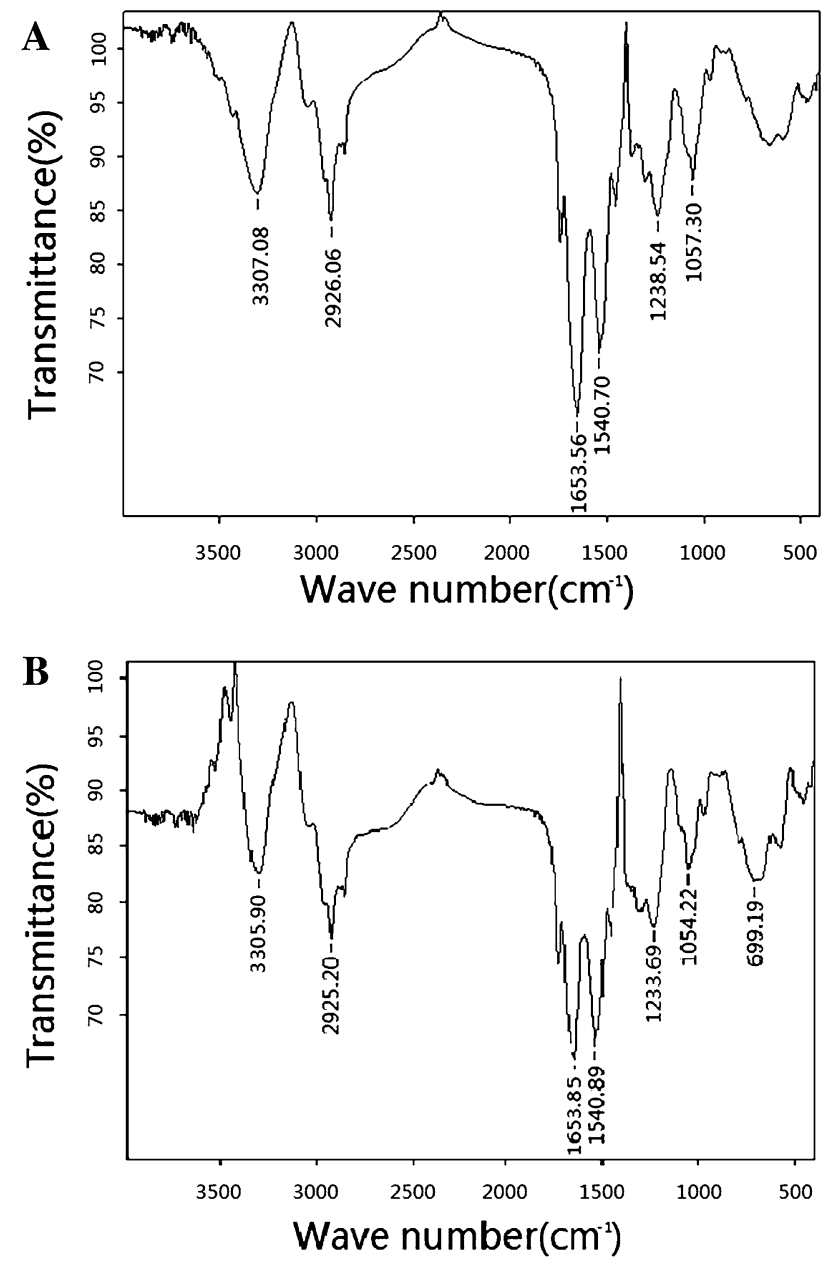

Fig. 9 FTIR spectra of BAPb.1 before (a) and after (b) adsorbing lead(II)

and copper(II) bonding, while the $\mathrm{C}-\mathrm{O}$ bond played an important role in lead(II) sorption (Pavasant et al. 2006). Moreover, some reports stated that the presence of amino, carboxyl, hydroxyl and carbonyl groups on the surface of the green algae Spirogyra, Pseudomonas aeruginosa ASU 6, Enterobacter cloacae strain P, which could be accountable for the bonding of lead (Tunali et al. 2006; Gupta and Rastogi 2008; Naik et al. 2012). These phenomena highlighted the fact that the hydroxyl, amino, amide, carbonyl, and phosphate groups were the available functional groups on Alcaligenes sp. $\mathrm{BAPb} .1$ cell surface associated with lead(II) biosorption.

\section{Conclusions}

The strain BAPb.1 showed high resistance to lead(II), copper(II), zinc(II), nickel(II), chromium(VI), kanamycin, ampicillin, streptomycin, chloramphenicol, and tetracycline. Under the optimum biosorption conditions, the maximum biosorption rate and capacity were $85.2 \%$ and $56.8 \mathrm{mg} \mathrm{g}^{-1}$. Equilibrium adsorption of the lead(II) by BAPb.1 biomass was well described by the Langmuir isotherm model. The biosorption mechanism includes ionic exchange interactions and complexation stages. This study reveals that the strain $\mathrm{BAPb} .1$ can serve as a potential biotechnological agent to bioremediate lead contaminated waters.

Acknowledgements This research was financially supported by the Natural Science Foundation of Heilongjiang Province, China (Grant Nos. D201402 and D2016001).

\section{Compliance with ethical standards}

Conflict of interest The authors declare that they have no conflict of interest in the publication.

\section{References}

Akinbowale OL, Peng H, Grant P, Barton MD (2007) Antibiotic and heavy metal resistance in motile aeromonads and pseudomonads 
from rainbow trout (Oncorhynchus mykiss) farms in Australia. Int J Antimicrob Agents 30:177-182

Batta N, Subudhi S, Lal B, Devi A (2013) Isolation of a lead tolerant novel bacterial species, Achromobacter sp. TL-3: assessment of bioflocculant activity. Indian J Exp Biol 51:1004-1011

Chatterjee SK, Bhattacharjee I, Chandra G (2010) Biosorption of heavy metals from industrial waste water by Geobacillus thermodenitrificans. J Hazard Mater 175:117-125

Chen C, Wen DH, Wang JL (2014) Cellular surface characteristics of Saccharomyces cerevisiae before and after $\mathrm{Ag}(\mathrm{I})$ biosorption. Bioresour Technol 156:380-383

Chergui A, Kerbachi R, Junter GA (2009) Biosorption of hexacyanoferrate(III) complex anion to dead biomass of the basidiomycete Pleurotus mutilus: biosorbent characterization and batch experiments. Chem Eng J 147:150-160

Chojnacka K, Chojnacki A, Górecka H (2005) Biosorption of $\mathrm{Cr}^{3+}$, $\mathrm{Cd}^{2+}$ and $\mathrm{Cu}^{2+}$ ions by blue-green algae Spirulina sp.: kinetics, equilibrium and the mechanism of the process. Chemosphere 59:75-84

Congeevaram S, Dhanarani S, Park J, Dexilin M, Thamaraiselvi K (2007) Biosorption of chromium and nickel by heavy metal resistant fungal and bacterial isolates. $\mathrm{J}$ Hazard Mater 146:270-277

Ding CC, Feng S, Cheng WC, Zhang J, Li XL, Liao JL, Yang YY, An Z, Luo SZ, Yang JJ, Tang J, Liu N (2014) Biosorption behavior and mechanism of thorium on Streptomyces sporoverrucosus dwc-3. J Radioanal Nucl Chem 301:237-245

Dong XZ, Cai MY (2001) Manual of systematic and determinative bacteriology. Science Press, Peking

EI-Sayed MT (2013) Removal of lead(II) by Saccharomyces cerevisiae AUMC 3875. Ann Microbiol 63:1459-1470

Freundlich HMF (1906) Über die adsorption in Lösungen. Zeitschrift fur Physikalische Chemie (Leipzig) 57:385-470

Gabr RM, Hassan SHA, Shoreitb MAA (2008) Biosorption of lead and nickel by living and non-living cells of Pseudomonas aeruginosa ASU 6a. Int Biodeterior Biodegrad 62:195-203

Gupta VK, Nayak A (2012) Cadmium removal and recovery from aqueous solutions by novel adsorbents prepared from orange peel and $\mathrm{Fe}_{2} \mathrm{O}_{3}$ nanoparticles. Chem Eng J 180:81-90

Gupta VK, Rastogi A (2008) Biosorption of lead from aqueous solutions by green algae Spirogyra species: kinetic and equilibrium studies. J Hazard Mater 152:407-414

Gupta VK, Srivastava SK, Mohan D, Sharma S (1998) Design parameters for fixed bed reactors of activated carbon developed from fertilizer waste for the removal of some heavy metal ions. Waste Manage 17:517-522

Gupta VK, Agarwal S, Saleh TA (2011) Synthesis and characterization of alumina-coated carbon nanotubes and their application for lead removal. J Hazard Mater 185:17-23

He JS, Chen JP (2014) A comprehensive review on biosorption of heavy metals by algal biomass: materials, performances, chemistry, and modeling simulation tools. Bioresour Technol 160:67-78

Huang F, Dang Z, Guo CL (2013) Biosorption of Cd(II) by live and dead cells of Bacillus cereus RC-1 isolated from cadmiumcontaminated soil. Colloid Surf B 107:1-18

Hubbe MA, Hasan SH, Ducoste JJ (2011) Cellulosic substrates for removal of pollutants from aqueous systems: a review. 1. Metals. Bioresources 6:2161-2287

Ilhan S, Nourbakhsh MN, Kilicarslan S, Ozdag H (2004) Removal of chromium, lead and copper ions from industrial waste waters by Staphylococcus saprophyticus. Electron J Biotechnol 2:50-57

Kazy SK, Das SK, Sar P (2006) Lanthanum biosorption by a Pseudomonas sp.: equilibrium studies and chemical characterization. J Ind Microbiol Biotechnol 33:773-783
Khadivinia E, Sharafi H, Hadi F, Zahiri HS, Modiri S, Tohidi A, Mousavi A, Salmanian AH, Noghabi KA (2014) Cadmium biosorption by a glyphosate-degrading bacterium, a novel biosorbent isolated from pesticide-contaminated agricultural soils. J Ind Eng Chem 20:4304-4310

Khani H, Rofouei MK, Arab P, Gupta VK, Vafaei Z (2010) Multiwalled carbon nanotubes-ionic liquid-carbon paste electrode as a super selectivity sensor: application to potentiometric monitoring of mercury ion(II). J Hazard Mater 183:402-409

Lan T, Feng Y, Liao JL, Li XL, Ding CC, Zhang D, Yang JJ, Zeng JH, Yang YY, Tang J, Liu N (2014) Biosorption behavior and mechanism of cesium-137 on Rhodosporidium fluviale strain UA2 isolated from cesium solution. J Environ Radioactiv 134:6-13

Langmuir I (1918) The adsorption of gases on plane surfaces of glass, mica and platinum. J Am Chem Soc 40:1361-1403

Latha S, Vinothini G, Dhanasekaran D (2015) Chromium [Cr(VI)] biosorption property of the newly isolated actinobacterial probiont Streptomyces werraensis LD22. 3 Biotech 5:423-432

Liu YJ, Pei X, Lin H, Gai P, Liu YC, Wu ZL (2012) Asymmetric bioreduction of activated alkenes by a novel isolate of Achromobacter species producing enoate reductase. Appl Microbiol Biotechnol 95:635-645

Masoudzadeh N, Zakeri F, Lotfabad TB, Sharafi H, Masoomi F, Zahiri SH, Ahmadian G, Noghabi KA (2011) Biosorption of cadmium by Brevundimonas sp. ZF12 strain, a novel biosorbent isolated from hot-spring waters in high background radiation areas. J Hazard Mater 197:190-198

Monteiro CM, Castro PML, Malcata FX (2011) Biosorption of zinc ions from aqueous solution by the microalga Scenedesmus obliquus. Environ Chem Lett 9:169-176

Naik MM, Pandey A, Dubey SK (2012) Biological characterization of lead-enhanced exopolysaccharide produced by a lead resistant Enterobacter cloacae strain P2B. Biodegradation 23:775-783

Ng SP, Davis B, Palombo EA, Bhave M (2009) A Tn5051-like mercontaining transposon identified in a heavy metal tolerant strain Achromobacter sp. AO22. BMC Res Notes 2:42-49

Onundi YB, Mamun AA, Khatib MFA, Ahmed YM (2010) Adsorption of copper, nickel and lead ions from synthetic semiconductor industrial wastewater by palm shell activated carbon. J Environ Sci Tech 7:751-758

Özcan AS, Tunali S, Akar T, Özcan A (2009) Biosorption of lead(II) ions onto waste biomass of Phaseolus vulgaris L.: estimation of the equilibrium, kinetic and thermodynamic parameters. Desalination 244:188-198

Pan JH, Liu RX, Tang HX (2007) Surface reaction of Bacillus cereus biomass and its biosorption for lead and copper ions. J Environ Sci China 19:403-408

Pavasant P, Apiratikul R, Sungkhum V, Suthiparinyanont P, Wattanachira S, Marhaba TF (2006) Biosorption of $\mathrm{Cu}^{2+}, \mathrm{Cd}^{2+}$, $\mathrm{Pb}^{2+}$, and $\mathrm{Zn}^{2+}$ using dried marine green macroalga Caulerpa lentillifera. Bioresour Technol 97:2321-2329

Puyen ZM, Villagrasa E, Maldonado J, Diestra E, Esteve I, Solé A (2012) Biosorption of lead and copper by heavy-metal tolerant Micrococcus luteus DE2008. Bioresour Technol 126:233-237

Ren GM, Jin Y, Zhang CM, Gu HD, Qu JJ (2015) Characteristics of Bacillus sp. PZ-1 and its biosorption to $\mathrm{Pb}(\mathrm{II})$. Ecotoxicol Environ Saf 117:141-148

Rodriguez CE, Quesada A, Rodriguez E (2006) Nickel biosorption by Acinetobacter baumannii and Pseudomonas aeruginosa isolated from industrial wastewater. Braz J Microbiol 37:465-467

Saleh TA, Gupta VK, Al-Saadi AA (2013) Adsorption of lead ions from aqueous solution using porous carbon derived from rubber tires: experimental and computational study. J Colloid Interface Sci 396:264-269 
Sedighi M, Ghasemi M, Hassan SHA, Wan RWD, Ismail M, Abdallah E (2012) Process optimization of batch biosorption of lead using Lactobacillus bulgaricus in an aqueous phase system using response surface methodology. World J Microbiol Biotechnol 28:2047-2055

Sen SK, Raut S, Dora TK, Mohapatra PKD (2014) Contribution of hot spring bacterial consortium in cadmium and lead bioremediation through quadratic programming model. J Hazard Mater 265:47-60

Sheng XF, Xia JJ, Jiang CY, He LY, Qian M (2008) Characterization of heavy metal-resistant endophytic bacteria from rape (Brassica napus) roots and their potential in promoting the growth and lead accumulation of rape. Environ Pollut 156:1164-1170

Souza MJD, Nair S, Bharathi PAL, Chandramohan D (2006) Metal and antibiotic-resistance in psychrotrophic bacteria from Antarctic marine waters. Ecotoxicology 15:379-384

Tripathi M, Vikram S, Jain RK, Garg SK (2011) Isolation and growth characteristics of chromium(VI) and pentachlorophenol tolerant bacterial isolate from treated tannery effluent for its possible use in simultaneous bioremediation. Indian J Microbiol 51:61-69

Tunali S, Çabuk A, Akar T (2006) Removal of lead and copper ions from aqueous solutions by bacterial strain isolated from soil. Chem Eng J 115:203-211

Ucuna H, Aksakal O, Yildiz E (2009) Copper(II) and zinc(II) biosorption on Pinus sylvestris L. J Hazard Mater 161:1040-1045

Vijayaraghavan K, Yun YS (2008) Bacterial biosorbents and biosorption. Biotechnol Adv 26:266-291

Zhang DY, Wang JL, Pan XL (2007) Cadmium sorption by EPSs produced by anaerobic sludge under sulfate-reducing conditions. J Hazard Mater 138:589-593

Zhu CW, Li ZP, Li DC, Xin Y (2014) Pb tolerance and bioaccumulation by the mycelia of Flammulina velutipes in artificial enrichment medium. J Microbiol 52:8-12 